\title{
Narrativas dos Pacientes com Hanseníase Sobre Ausência da Dor
}

\author{
Queiroz, Kelvia Karine Nunes; Oliveira, Mônica Cordeiro X. de; Lima, Isabelle \\ Siqueira; Leite, Dheyme Leoncio; Rodrigues, Mabell Sandy S.; Albuquerque, Vilma \\ L. S. Pires; Brandão, Márcia Valéria \\ Centro Universitário Christus - Unichristus — kelvia.karine@gmail.com
}

INTRODUÇÃO: a hanseníase é responsável por alterações de sensibilidade, deformidades incapacitantes e estigmas que causam impactos biopsicossociais e acarreta problemas de saúde pública para o Brasil que, apresenta-se como o segundo país mais endêmico do mundo. a dor é um sinal de alarme para a ocorrência de lesões teciduais e nos pacientes com hanseníase há, normalmente, uma ausência da dor. OBJETIVOS: Compreender a percepção dos pacientes com hanseníase sobre a ausência da dor; verificar se a ausência da dor compromete as atividades da vida diária; apreender como os pacientes vivenciam a doença e o estigma. MÉTODO: Tratase de uma pesquisa de campo com abordagem qualitativa, realizada com 4 pacientes de ambos os sexos, que residem no Centro de Convivência Antonio Justa, na cidade de Maracanaú-Ce, nos meses de abril e maio de 2011. Utilizamos a entrevista semi-estruturada e um diário de campo. o número de pacientes foi selecionado após um primeiro contato com os profissionais de saúde que estavam presentes diariamente no convívio do grupo com maior comprometimento de sensibilidade, de ambos os sexos e com idade acima de 18 anos. Nomes fictícios foram utilizados para preservação do anonimato. Os participantes foram abordados informalmente pela pesquisadora após a assinatura do Termo de Consentimento Livre e Esclarecido. RESULTADOS Os pacientes demonstraram sentimentos diversos frente a sua nova identidade como estigma e medos: "Olha.. tudo é leproso, se eu for lá vou pegar a lepra. Tocaram fogo na casa, na casa de farinha, não tinha mais nada". Embora o isolamento tenha sido abolido, sentemse despreparados para gerenciar suas vidas e continuam residindo no mesmo espaço que exercia o poder de controle dos seus corpos. a insensibilidade à dor interfere no seu dia a dia, sendo necessário o auto-cuidado. Os pacientes sentem-se abençoados pela ausência de dor: "Graças a Deus eu não sinto dor, é dormente as mãos, os pé, eu não acho nada... Bom é assim, não sentir dor". CONCLUSÃO: a Hanseníase continua sendo uma experiência existencial complexa e dolorosa que acarreta transformações na vida dos hansenianos, porém os pacientes ainda carregam no inconsciente imagens preestabelecidas sobre a "antiga lepra". o estigma é mais perceptível quando a doença esta relacionada as deformidades que trazem a descaracterização corporal e que são identificadas nas falas do medo, da culpa, da tristeza e da aversão à hanseníase. Apesar de relatarem a humilhação e preconceito, afirmam que não querem sair do seu local de moradia: "Eu gosto é daqui, de tá com os meus irmãos de sofrimento." Cabe ao profissional de saúde um cuidado humanizado, permanente e holístico, envolvendo os vários aspectos da vida do paciente. o principal aspecto que envolve a humanização fundamenta-se no fortalecimento do comportamento ético, em articular o cuidado técnico científico ao cuidado que incorpora o acolhimento e o respeito ao outro como ser autônomo e digno.

Queiroz, Kelvia Karine Nunes; Oliveira, Mônica Cordeiro X. de; Lima, Isabelle Siqueira; Leite, Dheyme Leoncio; Rodrigues, Mabell Sandy S.; Albuquerque, Vilma L. S. Pires; Brandão, Márcia Valéria. Narrativas dos Pacientes com Hanseníase Sobre Ausência da Dor. In: Anais do Congresso Internacional de Humanidades \& Humanização em Saúde [= Blucher Medical Proceedings, num.2, vol.1]. São Paulo: Editora Blucher, 2014. ISSN 2357-7282

DOI 10.5151/medpro-cihhs-10488 